\title{
15. Utbildningar i romanska språk vid Stockholms universitet
}

\section{Débora Rottenberg}

\subsection{Syfte, teori och metod}

Utbildningarna i romanska språk i Sverige är utformade på olika sätt även inom ett och samma lärosäte. Detta är fallet med de fyra romanska språken som erbjuds vid Romanska och klassiska institutionen på Stockholms universitet (SU). Syftet med denna undersökning är att ta reda på hur den nationella universitetspolicyn genomförs i dessa fyra utbildningar.

Allmänt kan begreppet policy förstås som grundprinciper för en organisations handlande (Nationalencyklopedin 2019). Utbildningspolicy definieras av Ball (1993) som både text och diskurs. I den här artikeln fokuseras på det första draget som tar sikte på policyn som består av texter vars riktlinjer genomförs i praktiken.

Denna undersöknings teoretiska inriktning, genomförandeteori (Ball et al. 2012), fokuserar på analysen av policyn i handling där texter avkodas, tolkas och åter kontextualiseras av olika aktörer och i olika kontexter. Dessa kontexter kan delas upp i fyra kategorier (Ball et al. 2012). Här appliceras de på den aktuella undersökningen:

1. den givna kontexten beror av institutionens fysiska placering, sammansättning och dess historia. Romanska och klassiska institutionen är ett resultat av en sammanslagning mellan den tidigare institutionen för franska, italienska och klassiska språk samt den tidigare institutionen för spanska, portugisiska och latinamerikastudier. Denna sammanslagning ägde rum i augusti 2013 med flytt till gemensamma lokaler.

2. den professionella kulturen kopplas till lednings- och lärarerfarenheter.

3. den materiella kontexten har att göra med bl.a. budget och infrastruktur; den är delvis lika för de fyra romanska språken vid SU med några skillnader som kan bero på olika faktorer som t.ex. antal studenter.

4. den externa kontexten, som är gemensam för alla fyra ämnen och knyter an till förväntningar från externa aktörer eller deras produkter som t.ex. 
den nationella lagstiftningen. En av de mest centrala lagtexterna är högskoleförordningen (SFS 1993:100) som anger de olika examensmålen.

I fallet SU finns det inga skillnader mellan högskoleförordningens examensmål och de lokala examensbeskrivningarna för de fyra romanska språken (Stockholms universitet 2017). Emellertid är utbildningarna utformade på olika sätt ${ }^{95}$.

För att kunna förstå hur den nationella policyn genomförts analyseras i det följande de kursplaner som gällde HT16 från nivå I till kandidatnivå inom ämnena franska, italienska, portugisiska och spanska ${ }^{96}$. Analysmetoden är komparativ. Först jämförs de olika kursernas upplägg nivå för nivå med utgångspunkt i kursplanernas angivna delkursinriktningar. Därefter kommenteras på ett övergripande sätt relationen mellan delkursernas innehåll, förväntade studieresultat och examination utifrån det som framgår av kursplanerna i förhållande till högskoleförordningens examensmål.

\subsection{Analys}

\subsubsection{Nivå I: upplägg}

På nivå I tränar alla fyra ämnen de fyra grundläggande färdigheterna: läsförståelse, hörförståelse, muntlig färdighet och skriftlig färdighet. Som framgår av Tabell 1 har de olika färdigheterna dock getts olika viktning. Förutom träning i dessa färdigheter ingår i alla ämnen dessutom studiet av grammatik, litteratur samt kultur och samhälle. De olika momenten organiseras i delkurserna med tillhörande högskolepoäng på följande sätt:

95 Dessa skillnader kan inte riktigt förklaras med de olika förkunskapskraven: portugisiska har ingen särskild behörighet. Franska har Franska 3/ steg 3 eller vissa universitets förberedande-/ nybörjarkurser. Spanska har Spanska 3/ steg 3/C-språk B eller SUs nybörjarkurs (i kursplanen). Slutligen har italienska Italienska $2 /$ steg 2 eller vissa universitets förberedande-/nybörjarkurser.

96 Det som vid SU kallas för nivå I motsvarar 0-30 hp, nivå II motsvarar 31-60 hp, nivå III motsvarar 61-90 hp och kandidatnivån motsvarar 91-120 hp. Detta skiljer sig från andra lärosäten på två sätt. För det första är beteckningarna inte desamma; exempelvis heter Spanska I vid SU Spanska $A$ vid Uppsala universitet. För det andra skriver spanskstudenter vid SU sina kandidatuppsatser den fjärde terminen, dvs när de har $90 \mathrm{hp}$, medan studenter vid andra lärosäten skriver kandidatuppsats i spanska efter att ha läst $60 \mathrm{hp} \mathrm{i} \mathrm{ämnet.}$ 
Tabell 1. Upplägg för utbildningarna i romanska språk vid SU, Nivå I

\begin{tabular}{|c|c|c|c|}
\hline Franska I & Italienska I & Portugisiska I & Spanska I \\
\hline Fonetik, $2 \mathrm{hp}$ & & & Fonetik, $3 \mathrm{hp}$ \\
\hline Uttal, $1,5 \mathrm{hp}$ & & & Uttal, 2 hp \\
\hline $\begin{array}{l}\text { Muntlig kommuni- } \\
\text { kation, } 4 \mathrm{hp}\end{array}$ & $\begin{array}{l}\text { Muntlig kommunika- } \\
\text { tion, } 7,5 \mathrm{hp}\end{array}$ & $\begin{array}{l}\text { Muntlig färdighet och } \\
\text { interaktion I, } 7,5 \mathrm{hp}\end{array}$ & \\
\hline $\begin{array}{l}\text { Kultur och samhälle } \\
\text { i Frankrike, } 7,5 \text { hp }\end{array}$ & $\begin{array}{l}\text { Italiensk geografi och } \\
\text { samhälle, } 3 \mathrm{hp} \\
\text { Italiensk kultur och } \\
\text { historia, } 4,5 \mathrm{hp}\end{array}$ & $\begin{array}{l}\text { Portugisiska i världen, } \\
7,5 \mathrm{hp}\end{array}$ & $\begin{array}{l}\text { Spaniens historia och } \\
\text { geografi, } 3,5 \mathrm{hp} \\
\text { Spanskamerikas historia } \\
\text { och geografi, } 4 \mathrm{hp}\end{array}$ \\
\hline $\begin{array}{l}\text { Grammatik och } \\
\text { ordförråd, } 5 \mathrm{hp} \\
\text { Språkanalys och } \\
\text { ordförråd, } 2,5 \mathrm{hp} \\
\text { Modern fransk } \\
\text { litteratur, } 7,5 \mathrm{hp}\end{array}$ & $\begin{array}{l}\text { Italiensk grammatik, } \\
4,5 \mathrm{hp} \\
\text { Skriftlig produktion, } \\
3 \mathrm{hp} \\
\text { Italiensk litteratur } \\
7,5 \mathrm{hp}\end{array}$ & $\begin{array}{l}\text { Text och språkstruktur } \\
\text { I, } 7,5 \text { hp } \\
\text { Text och språkstruktur } \\
\text { II, } 7,5 \text { hp }\end{array}$ & $\begin{array}{l}\text { Grammatik, 7,5 hp } \\
\text { Text och litteratur I, } \\
5 \text { hp } \\
\text { Text och litteratur II, } \\
5 \text { hp }\end{array}$ \\
\hline
\end{tabular}

\subsubsection{Nivå I: innehåll, förväntade studieresultat och examination}

\section{Fonetik och uttal}

Tabell 1 visar att Italienska I och Portugisiska I inte har några specifika delkurser i fonetik och uttal. Inom italienskan ingår dessa som moment i delkursen "Muntlig kommunikation", dock är de förväntade studieresultaten bara relaterade till uttal och inte till fonetik. I Portugisiska I ingår fonetik och uttal i "Muntlig färdighet och interaktion". Det finns förväntade studieresultat för fonetik, dock inte för uttal.

När det gäller uttal i Spanska I är förväntat studieresultat att uttala spanska "på ett för nivån tillfredsställande sätt", en formulering som är något vag. I jämförelse är då de förväntade studieresultaten i kursplanen för Franska I mer detaljerade.

Om man ställer fonetikdelkurserna i Spanska I och Franska I mot varandra kan det konstateras att studenterna i Spanska I ska kunna identifiera 
regionala varianter medan franskans varianter tas upp först på nivå II:s delkurs i frankofoni ${ }^{97}$.

\section{Muntlig uttrycksfärdighet}

Som framgår av Tabell 1 har Spanska I inte några separata delkurser som tränar studenten i muntlig uttrycksfärdighet, utan den kompetensen tillägnas i de delkurser som behandlar text och skriftlig produktion samt historia och geografi. Några indikationer på specifika hörförståelsemoment finns inte. Den färdigheten övas i genomgångar och med multimedialt material inom flera delkurser som t.ex. "Den spansktalande världen". I Portugisiska I övas hörförståelsen i samband med den allmänna grammatiken. Det finns inga specifika förväntade studieresultat för denna färdighet. I Italienska I nämns aspekten överhuvudtaget inte. I Franska I, däremot, tränas hörförståelse inom blocket "Muntlig kommunikation”. Studenterna förväntas förstå tal på standardfranska av allmänt innehåll, vilket examineras med 2-3 prov.

\section{Kultur och sambälle samt historia och geografi}

Alla fyra ämnen ägnar 7,5 hp åt detta område om än fördelade på olika sätt. Det som skiljer ämnena åt är att vissa lägger fokus på ett land och andra på flera. I fallet Franska I är delkursen centrerad kring Frankrike. Detsamma gäller Italienska I som är koncentrerad till Italien. Däremot omfattar studierna både i Portugisiska I och i Spanska I flera länder: inom portugisiskan behandlas de områden där portugisiska har officiell status och inom spanskan både Spanien och länderna i Latinamerika.

Både franska och portugisiska har förväntade studieresultat relaterade till kritisk tolkning av information och källkritik, vilket de andra två ämnena saknar.

\section{Resterande moment}

Som framgår av Tabell 1 skiljer sig ämnena i sättet på vilket de fördelar och kombinerar undervisning och inlärning av skriftlig uttrycksfärdighet, grammatik och litteratur.

97 Frankofoni kan förstås som samlingen av de fransktalande gemenskaperna i världen. För en fördjupning och en diskussion av termen, se Premat (2018). 


\section{Skriftlig uttrycksfärdighet}

Italienska I är det enda ämne som har en separat delkurs i skriftlig produktion; den behandlar grundläggande aspekter i syntax och träning av det centrala ordförrådet. Portugisiska I samlar träning i skriftlig språkfärdighet, grammatik och läsning av texter i två på varandra följande delkurser. Spanska I, i sin tur, kombinerar skriftlig språkfärdighet med muntlig språkfärdighet och textläsning, i två på varandra följande delkurser ${ }^{98}$.

\section{Litteratur}

I Spanska I behandlas skönlitteratur tillsammans med icke skönlitterära texter, medan Italienska I och Franska I har separata delkurser i litteratur.

Gemensamt för alla ämnen är att studenterna förväntas förstå eller tillgodogöra sig de lästa texterna. I portugisiska behandlas enkla texter. I ämnet spanska analyseras texter från olika genrer, medan franska koncentrerar sig på prosatexter från mitten av 1950 till våra dagar. Precis som i de andra momenten fokuserar ämnet franska på fransk litteratur, inte franskspråkig, och italienska på italiensk. Däremot läses i ämnet spanska litterära texter från olika delar av den spanskspråkiga världen.

I spanska, italienska och franska presenteras grundläggande litteraturvetenskapliga begrepp. I både franska och spanska lär sig studenterna även grundläggande analysmetoder. Studenterna förväntas kunna redogöra för verkens innehåll, diskutera kring dem och göra enklare analyser. Studenterna i italienska förväntas kunna förklara ord och uttryck från de lästa texterna som i franskans "Språkanalys och ordförråd". I Spanska I och Franska I förväntas studenterna kunna redogöra för eller definiera litterära grundbegrepp för att kunna tillämpa dem i analyser och tolkningar.

\section{Grammatik}

Ämnena skiljer sig åt i tre aspekter. Avseende inlärning av ordförråd anges det för Franska I att studenterna ska behärska cirka 2500 ord och uttryck av det centrala franska ordförrådet, vilket tränas med övningar under delkursen. Detta tyder på ett systematiskt och medvetet arbete med ordkunskap. I

98 Man kan påpeka att längst utbildningarna tränas den skriftliga uttrycksfärdigheten i flera olika delkurser, utöver de i strikt skriftlig uttrycksfärdighet. Dessutom är flera examinationsuppgifter skriftliga. Ändå saknas många gånger information kring förväntade studieresultat rörande den färdigheten på dessa andra delkurser. Det kan leda till att studenterna slarvar med det skriftliga och bara koncentrerar sig på innehållet, trots att form och innehåll egentligen inte kan separeras. 
Portugisiska I nämns att de lästa texterna ger ett grundläggande ordförråd som studenterna ska tillägna sig (Text I) eller känna igen (Text II). I Italienska I ingår träning av det centrala ordförrådet som en del av innehållet i "Skriftlig produktion". Spanska I nämner inte inlärandet av ordkunskap, med undantag för "Den spansktalande världen" där studenterna förväntas behärska spanskans specifika ordförråd inom historia och geografi.

Vad gäller svenskans roll i undervisning och inlärning nämns varken i Italienska I eller i Portugisiska I något om användningen av svenska. I Franska I anges under delkursens innehåll att det till viss del anläggs ett kontrastivt perspektiv. Det finns emellertid inga förväntade studieresultat angående detta perspektiv, vilket kan tolkas som att det kontrastiva används för att belysa skillnader språken emellan, medan det som studenterna förväntas kunna är fransk grammatik. Däremot står det i Spanska I att träning i mediering mellan spanska och svenska är ett inslag i delkursen, vilket innebär att studenterna utför viss översättning. Emellertid står det ingenting om detta som förväntat studieresultat, utan det står att studenterna ska kunna resonera kring strukturella skillnader språken emellan.

Avseende krav på användning av olika slags språkkunskaper förväntas studenterna i Portugisiska I förvärva kunskap i formlära och syntax, men det är inte tydligt om detta visas genom tillämpning av den kunskapen eller i form av redogörelser för den. I Italienska I förväntas studenterna kunna redogöra för regler och tillämpa dem i analyser, däremot förväntas de inte besitta aktiv kunskap och användning av dessa. Både Franska I och Spanska I kräver analytisk kunskap i och med att vissa av de förväntade resultaten har med grammatisk eller lingvistisk analys att göra.

Sammanfattningsvis kan man konstatera att när det gäller kursplanerna på nivå I har den yttre kontexten tolkats olika språken emellan. De två viktigaste skillnaderna har att göra med högskoleförordningens examensmål som relaterar till kunskap och förståelse samt till färdighet och förmåga.

I det första fallet, begränsar franskan, liksom italienskan, kunskap och förståelse inom huvudområdet genom att koncentrera sig på ett land inom den europeiska språkgemenskapen, dvs. Frankrike respektive Italien, till skillnad från spanskan och portugisiskan, som anlägger ett utomeuropeiskt perspektiv. En möjlig förklaring relaterad till det Ball et al. (2012) anför om professionella kontexter är att det inom lärargruppen som har undervisat i 
spanska och portugisiska under de senaste 30 åren har funnits personer som kommer från eller länge har bott på flera olika ställen både i Latinamerika och i Afrika. Dessa lärare har mångfacetterade erfarenheter som förmodligen har influerat utformningen av kursplanerna.

I det andra fallet, som gäller kontextualiseringen av målen för färdighet och förmåga, främjar franskans kursplaneutformning de mål som är relaterade till förmågan att muntligt redogöra för och diskutera information, problem och lösningar. Dessutom inkluderar både franska och portugisiska mål om förmågan att kritiskt tolka information utifrån en problemställning.

\subsubsection{Nivå II: upplägg}

Tabell 2 Upplägg för utbildningarna i romanska språk vid SU, Nivå II

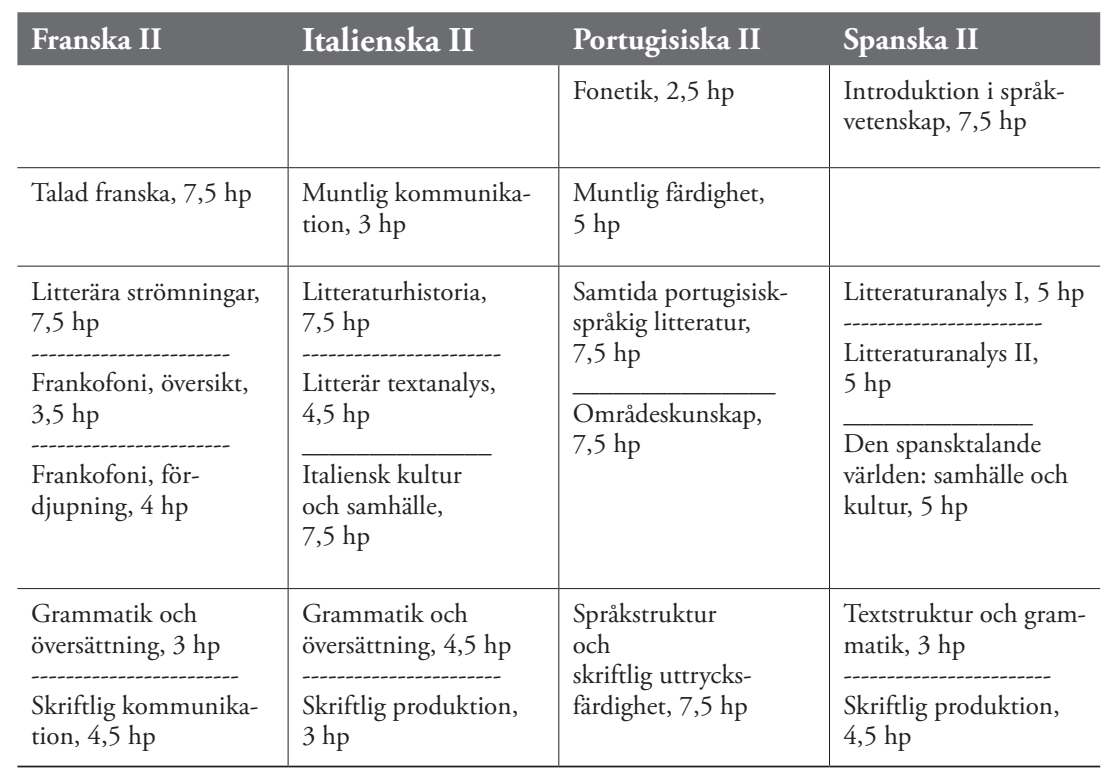

\subsubsection{Nivå II: innehåll, förväntade studieresultat och examination}

På nivå II finns tre skillnader språken emellan. Den viktigaste är att Spanska II har en introduktionskurs i språkvetenskap, vilken de andra ämnena inför först på nivå III. Delkursen behandlar spanskans morfologi, syntax och semantik, språkhistoria och regionala varieteter. 
Den andra skillnaden är att Spanska II återigen inte har någon specifik delkurs i muntlig färdighet, utan att det momentet är inkluderat i de andra delkurserna. Den sista är att Portugisiska II har fonetik, vilket de andra ämnena har som delkurs eller moment på nivå I.

Härnäst kommenteras delkurserna med samma inriktning.

\section{Muntlig uttrycksfärdighet}

I både Franska II och Italienska II behandlas förståelse av, redogörelse för och egen produktion av det talade språket. I franska följer man en tydlig röd tråd mellan delkursinnehåll, förväntade studieresultat och examination. I italienska finns det inga uttalade förväntade studieresultat med avseende på förståelse eller redogörelse, utan bara om egen produktion, även om "att interagera" innebär en viss förståelse.

Portugisiska II fokuserar på förmågan att kommunicera och reflektera över kommunikationssituationer och den egna inlärningsprocessen. Både förväntade studieresultat och examination stämmer överens med kursinnehållet.

\section{Kultur och sambälle}

Delkursen inom Spanska II fokuserar på nutida samhällsliv och kulturella förhållanden i den spansktalande världens olika delar. Italienska II fokuserar på det italienska samhällets utveckling under en specifik period eller utifrån ett specifikt tema.

Både Franska II och Portugisiska II kombinerar dåtid och nutid som studieobjekt. Portugisiska behandlar de portugisiskspråkiga ländernas historia, geografi, samhällsliv och kulturella förhållanden. Texterna studeras också ur en språklig synvinkel. Franska II anlägger ett bredare anslag än på Franska I och omfattar frankofonin, vilket inkluderar ett litterärvetenskapligt perspektiv med studium av några franskspråkiga författarskap.

I alla ämnena förväntas studenterna kunna visa kunskap om, redogöra för, kommentera eller diskutera kulturella och samhälleliga aspekter som behandlas inom delkurserna. Detta innebär att även spanskan här inkluderar mål förknippade med att muntligt kunna redogöra för och diskutera information. Studenterna i Franska II förväntas dessutom kunna formulera problemställningar för att analysera dessa aspekter. Inom franska och portugisiska förväntas de också kunna använda relevanta informationskällor. 


\section{Grammatik}

Spanska II är som redan delkursens namn, "Textstruktur och grammatik", antyder tydligt inriktad på textgrammatik. Delkursen fokuserar på genomgångar av syntaktiska och diskursiva aspekter såsom ordföljd, diskursmarkörer, koherens och kohesion, som studenterna förväntas kunna använda och i vissa fall förklara. Portugisiska II behandlar olika aspekter av modern portugisiska. Studenterna förväntas kunna redogöra för centrala aspekter av språkets grammatik, tillämpa dessa i skrift och behärska centrala delar av det portugisiska ordförrådet. Enligt kursplanerna anlägger varken Spanska II eller Portugisiska II ett kontrastivt perspektiv, vilket däremot ingår i de andra ämnena i form av översättning till franska respektive italienska. Det finns inga förväntade studieresultat angående översättning vilket kan tolkas som att översättning inte är en färdighet som ska läras in utan mer fungerar som ett verktyg för inlärning av grammatik och språkstruktur. Däremot finns det detaljerade förväntade studieresultat som anger vilka specifika språkaspekter studenterna ska behärska. Spanska och portugisiska saknar den här detaljrikedomen som ger bra vägledning till studenterna.

\section{Skriftlig uttrycksfärdighet}

Alla fyra ämnena kombinerar teoretiska moment med praktiska övningar. Spanska II och Italienska II koncentrerar sig på akademiska genrer medan de andra två ämnena behandlar olika genrer.

Portugisiska II fokuserar på korrekt tillämpning av grammatiska regler och ordförråd i olika texttyper. Franska II lägger tonvikten på textbindning samt register- och genremarkörer. Spanska II koncentrerar sig på tillämpning av skrivregler och stilnormer, vilket inbegriper förmåga att kunna använda och citera källor och referenser. Delkursen "Frankofoni” har en fördjupningsdel där studenterna bland annat förväntas "söka upp, välja, kritiskt granska och använda relevanta informationskällor, redigera en dokumenterad och utredande skriftlig framställning på franska [samt] använda ett vedertaget referenssystem vid författande av uppsats" (Stockholms universitet 2015b). Det är ett tidigt steg i arbetet med den skriftliga språkförmågan för att underlätta vägen till att skriva kandidatuppsats.

Alla ämnena förutom spanska har som förväntat studieresultat att studenterna ska behärska eller kunna använda ett utvecklat ordförråd (centralt 
ordförråd i portugisiskan). Alla ämnen förutom italienska har förväntade studieresultat angående att skriva med språklig korrekthet eller att inte avlägsna sig från standardiserade skriftspråksnormer. Både spanska och portugisiska betonar vikten av att skriva korrekt och av att bearbeta de egna texterna, vilket tyder på en syn om skrivandet som en process. Både franska och italienska har användningen av en komplex syntax som förväntat studieresultat.

\section{Litteratur}

Litteraturstudiet på denna nivå inbegriper både litteraturanalys och litteraturhistoria. Franska, italienska och i viss mån portugisiska genomför mera systematiska studier av litteraturens utveckling över tid än vad spanska gör. I Italienska II studeras kanoniska italienska texter och studenterna tränas i förmågan att identifiera tidstypiska drag i skönlitterära texter. I Franska II behandlas estetiska och idéhistoriska strömningar inom den franska litteraturen från 1600-talet till modern tid. Båda delkurserna har som förväntat studieresultat att kunna analysera och diskutera skönlitterär text; att kunna redogöra för huvudlinjerna i litteraturhistorien samt att kunna placera ett urval litterära texter i sitt sammanhang. Inom franskan betonas att det är estetiska och idéhistoriska strömningar det handlar om.

Portugisiska II behandlar portugisiskspråkig litteratur från 1930-talet till våra dagar, ungefär samma period som litteraturkursen på Franska I. Delkursen fokuserar på det litteraturhistoriska sammanhanget: studenterna förväntas förvärva en allmän bild av den historisk-litterära utvecklingen i den portugisiskspråkiga världen under de senaste 80 åren, vilken examineras med flera inlämningsuppgifter om den litterära utvecklingen. Delkursen lyfter frågor om genus i litteraturen, vilken studenterna förväntas kunna värdera.

Spanska II har två delkurser i litteratur som bygger på varandra. Enligt de förväntade studieresultaten handlar den första delkursen om samtida text. Tonvikten ligger på att analysera verken, sätta dem i sitt historiska och sociokulturella sammanhang samt redogöra för sekundärlitteratur. Den andra delkursen är inte inriktad på någon särskild epok. I stället ligger fokus på fördjupning av de litteraturvetenskapliga metoderna och begreppen samt sökning, granskning och redogörelse för sekundärlitteratur. 
Förutom de redan nämnda kurserna med ett litteraturhistoriskt perspektiv, har både franska och italienska ytterligare en delkurs i litteratur. I franska ingår, som redan nämnts, en del av litteraturstudiet i delkursen "Frankofoni”. I italienska fokuserar delkursen "Litterär textanalys" på presentation av litteraturvetenskapliga begrepp och tillämpning av dessa i analys av verk som sätts i kontext. De förväntade studieresultaten överensstämmer bara delvis med innehållet i och med att ingenting står om att sätta verken i sin kontext; däremot förväntas studenterna kunna redogöra för verkets innehåll, vilket är mer grundläggande än det som står under delkursens beskrivning.

Sammanfattningsvis vad gäller nivå II kan man konstatera att den viktigaste skillnaden mellan högskoleförordningen och de fyra ämnenas kursplaner är kopplad till de examensmål som relaterar till kunskap och förståalse. Spanskan betonar kunskapen inom språkvetenskap mer än resterande ämnen. Dessutom märks olika föreställningar om vilken typ av kunskap inom huvudområdet som är viktig i kurserna i skönlitteratur där spanska skiljer sig genom att inte värdera litteraturhistoria lika mycket som de andra ämnena.

\subsubsection{Nivå III: upplägg}

Tabell 3 Upplägg för utbildningarna i romanska språk vid SU, Nivå III

\begin{tabular}{|c|c|c|c|}
\hline Franska III ${ }^{99}$ & Italienska III & Portugisiska III & Spanska III \\
\hline $\begin{array}{l}\text { Valbar delkurs: Kultur } \\
\text { och identitet, 7,5 hp }\end{array}$ & $\begin{array}{l}\text { Italiensk kultur- och } \\
\text { samhällskunskap, } \\
7,5 \mathrm{hp}\end{array}$ & & \\
\hline \begin{tabular}{l} 
Akademisk text, 4,5 hp \\
Utredande text, $3 \mathrm{hp}$ \\
\hdashline Språkstruktur, $2,5 \mathrm{hp}$
\end{tabular} & \begin{tabular}{l} 
Skriftlig produktion, \\
$4,5 \mathrm{hp}$ \\
\hdashline Grammatik och \\
översättning, $3 \mathrm{hp}$
\end{tabular} & $\begin{array}{l}\text { Skriftlig uttrycks- } \\
\text { färdighet, } 5 \mathrm{hp} \\
\text { Mediering, } 5 \mathrm{hp}\end{array}$ & $\begin{array}{l}\text { Skriftlig uttrycks- } \\
\text { färdighet och } \\
\text { mediering, } 7,5 \mathrm{hp}\end{array}$ \\
\hline
\end{tabular}

99 Studenterna läser fyra obligatoriska och två valbara delkurser. Metodkurserna, till skillnad från övriga valbara delkurser, ger behörighet att skriva examensarbete på kandidatnivå. 


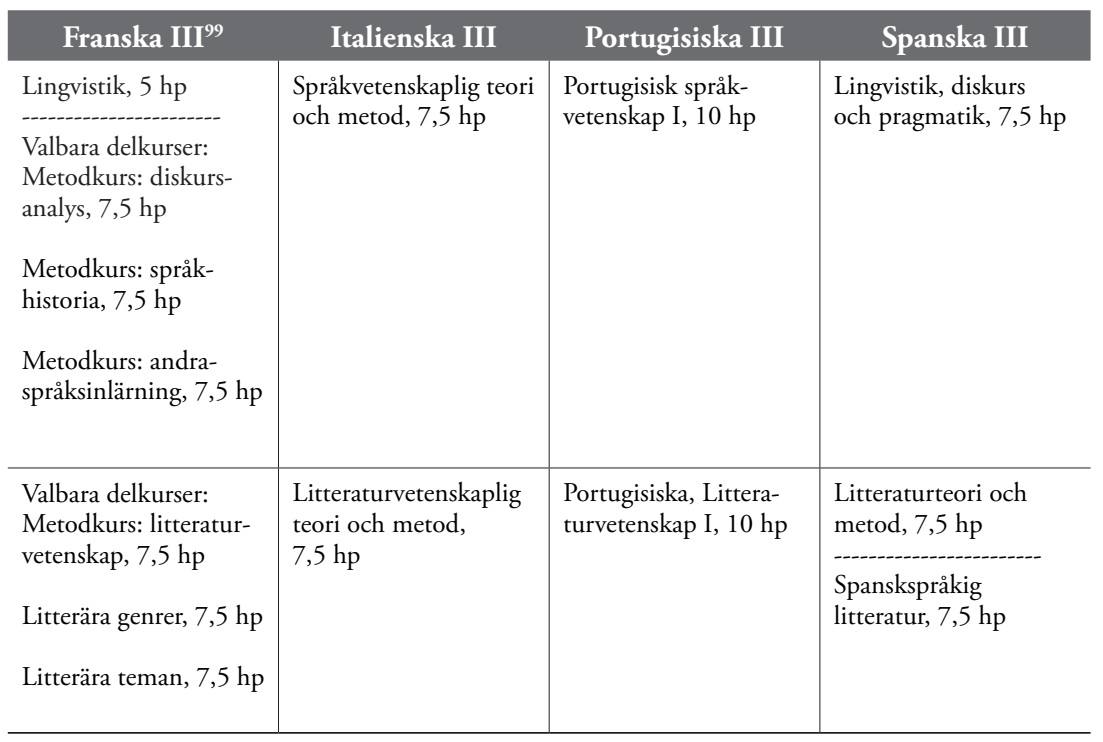

\subsubsection{Nivå III: innehåll, förväntade studieresultat och examination}

Av tabell 3 framgår att franska är det enda ämne som erbjuder valbara delkurser redan på nivå III. Samma delkurser erbjuds på kandidatnivån och kommenteras nedan under 2.8.

På tredje nivån är italienska det enda ämne som har en obligatorisk delkurs i kultur- och samhällskunskap; den behandlar det italienska samhällets utveckling från mitten av 1900-talet till idag.

På den här nivån finns en stomme av obligatoriska moment som är gemensamma för alla fyra ämnen och som jämförs här nedan: skriftlig produktion, grammatik, litteratur och lingvistik.

\section{Skriftlig uttrycksfärdighet}

På nivå III fokuserar portugisiska på förmågan att skriva texter med tonvikt på akademiska skriftliga genrer. Likaså studeras akademiska texter på delkursen "Akademisk text" på Franska III så att studenterna därefter ska kunna skriva egna vetenskapliga texter och delta i en ventilering. I både portugisiska och franska är de förväntade studieresultaten tydliga och motsvarar delkursernas innehåll. Det handlar, bland annat, om att kunna 
uppvisa kunskap om akademiska genrestrukturer och att producera texter som följer akademiska genrekonventioner, såsom textbindning och akribi.

I Franska III övas också den skriftliga uttrycksfärdigheten på delkursen "Utredande text" där modeller för disposition och argumentation samt teknik för att behandla stoff och utforma den skriftliga framställningen presenteras. Studenterna förväntas kunna skriva utredande text med korrekt disposition och överskådliga resonemang, vilket examineras genom salstentamen.

Delkursen i Italienska III behandlar grammatiska moment med tonvikt på textbindning, interpunktion, register- och stilmarkörer. Studenterna förväntas kunna skriva olika typer av texter på italienska, kunna reflektera över egna texter och deras funktion i olika kommunikativa sammanhang samt identifiera och analysera grammatiska konstruktioner i givna texter.

I Spanska III ingår skriftlig färdighet i en delkurs tillsammans med mediering. Kursinnehållet och de flesta förväntade studieresultaten är relaterade till mediering. Angående själva den skriftliga uttrycksfärdigheten står det under innehåll att det ingår träning i att skriva texter på spanska med tonvikt på akademiska genrer. Under förväntade studieresultat står det att studenterna ska kunna skriva kortare texter på genreanpassad, idiomatisk och grammatisk korrekt spanska inom akademiska såväl som journalistiska genrer.

\section{Grammatik, språkstruktur och mediering}

Franska III är det enda ämne som inte anlägger ett kontrastivt perspektiv utan i delkursen Språkstruktur lägger tonvikten på den skrivna franskans språkstruktur vad beträffar grammatik och vokabulär utifrån modern språkteori.

Däremot anlägger de andra ämnena ett kontrastivt perspektiv i grammatikstudiet. I italienskan förväntas studenterna kunna använda lexikon och grammatikor samt att kunna översätta i båda riktningar. I portugisiskan handlar det om att kunna mediera till portugisiska och att i skrift tillämpa strukturer i den portugisiska grammatiken. I spanska förväntas studenterna bland annat kunna "beskriva skillnader mellan spanskans och svenskans språkstrukturer samt mellan språkens skrivkonventioner inom journalistiska och akademiska genrer, utföra enklare skriftliga medieringsuppgifter mellan språken, främst till spanska [samt] uppvisa god stilistisk förmåga i samband med medieringsuppgifter till spanska” (Stockholms universitet 2012f). 


\section{Litteratur}

Alla fyra ämnen har en delkurs i litteraturvetenskaplig teori och metod. Franskans valbara "Metodkurs: teori och metod" inkluderas här eftersom den är jämförbar med de andra.

Gemensamt för spanska, franska och italienska är att studenterna förväntas kunna identifiera, redogöra för eller orientera sig inom olika litteraturvetenskapliga teorier och metoder samt applicera dem på skönlitterär text. Franska och spanska kräver dessutom en högre grad av medvetenhet om de teorier som gås igenom, i och med att studenterna ska göra relevanta teorioch metodval för enskilda analyser eller diskutera och värdera tolkningar utifrån olika teoribildningar. Båda ämnena kräver också att studenterna ska planera ett forskningsprojekt eller presentera en teoretisk och metodologisk grund för en forskningsuppgift inom litteraturvetenskap.

Portugisiska lägger i sin tur fokus på narratologiska metoder och litterära genrer, analys av aspekter relaterade till intersektionalitet samt kunskap om de portugisiskspråkiga ländernas historia, samhälle och kultur.

Spanska III har ytterligare en litterär delkurs, vilken främst fokuserar på litterär analys. Inom "Spanskspråkig litteratur" läses texter från de spansktalande länderna. Inga begränsningar om perioder eller genrer anges. De förväntade studieresultaten är bland annat att studenten ska kunna tolka dessa texter med stöd av litteraturvetenskapliga teorier och metoder samt placera in dem i deras sociokulturella sammanhang. Dessutom förväntas studenterna att med litteraturvetenskaplig stringens kunna uttrycka sig på akademisk spanska.

Språkvetenskap

Alla fyra ämnen erbjuder en kurs i språkvetenskapliga teorier och metoder. Innehållet och de förväntade studieresultaten skiljer sig dock ämnena emellan. Både Franska III och Portugisiska III behandlar morfosyntax, semantik och pragmatik. Italienska III tar upp fonologi, morfosyntax och semantik, men inte pragmatik. Spanska III koncentrerar sig på pragmatik och diskursanalys (morfosyntax och semantik ingår på nivå II) samt en orientering i samspelet mellan språkets formella strukturer och dess funktioner som uttrycks- och kommunikationsmedel. Dessutom ger Italienska III en introduktion till 
språktypologi och Portugisiska III en presentation av några huvuddrag i språkets utveckling och en genomgång av de viktigaste regionala särdragen.

Alla ämnen har som förväntat studieresultat att studenten ska kunna redogöra för begrepp inom de behandlade områdena. Inom franskan, italienskan och portugisiskan förväntas studenterna kunna tillämpa dessa begrepp, samt ett antal teorier, metoder och beskrivningsmodeller i språkanalys. Dessutom förväntas studenter i franska att utifrån olika förklaringsmodeller kunna reflektera kring autentiskt språkbruk; studenterna i portugisiska förväntas kunna redogöra för skillnaden mellan tal- och skriftspråk samt översiktligt kunna beskriva det portugisiska språkets utveckling från latin till modern portugisiska. I spanska ska studenterna "kunna förhålla sig kritiskt till forskningsresultat och upptäcka och formulera forskningsproblem samt uttrycka sig på spanska på ett adekvat sätt med hänsyn till ämnesområdet” (Stockholms universitet 2012f).

Sammanfattningsvis kan man konstatera att när det gäller nivå III är de viktigaste skillnaderna mellan de fyra ämnenas kursplaner i förhållande till högskoleförordningen kopplade till de examensmål som relaterar till kunskap och förståelse samt till färdighet och förmåga.

I det första fallet, som avser kunskaps- och förståelsemålen, handlar det om tre aspekter. Till att börja med erbjuder franskan med sina valbara metodkurser en tidigare fördjupning inom någon del av huvudområdet (se 2.8). Dessutom visar det teoretiska djupet i skönlitterturkurserna en skillnad mellan portugisiska och de andra ämnena i och med att läsningen begränsas till några få litteraturvetenskapliga teorier och metoder, vilket gör att områdets vetenskapliga grund förtunnas något. Vidare skiljer sig italienskan från de andra ämnena i de områden som tas upp inom språkvetenskap.

I det andra fallet, färdighets- och förmågemålen, kontextualiserar franskan och portugisiskan, tack vare fokuset på akademiskt skrivande, examensmålet om förmågan att skriftligt kunna redogöra för och diskutera information, problem och lösningar på ett tydligare sätt än spanskan och portugisiskan, som såväl i kursens innehåll som i förväntade studieresultat spänner över flera genrer. 


\subsubsection{Kandidatnivå: upplägg}

Tabell 4 Upplägg för utbildningarna i romanska språk vid SU, kandidatnivå

\begin{tabular}{|c|c|c|c|}
\hline $\begin{array}{l}\text { Franska } \\
\text {-kandidatkurs }{ }^{100}\end{array}$ & $\begin{array}{l}\text { Italienska } \\
\text {-kandidatkurs }^{101}\end{array}$ & $\begin{array}{l}\text { Portugisiska } \\
\text {-kandidatkurs }\end{array}$ & $\begin{array}{l}\text { Spanska } \\
\text {-kandidatkurs }^{102}\end{array}$ \\
\hline $\begin{array}{l}\text { Examensarbete för } \\
\text { kandidatexamen, } \\
15 \mathrm{hp}\end{array}$ & $\begin{array}{l}\text { Italienska, examens- } \\
\text { arbete för kandidat- } \\
\text { examen, } 15 \mathrm{hp}\end{array}$ & Examensarbete, $15 \mathrm{hp}$ & Examensarbete, $15 \mathrm{hp}$ \\
\hline $\begin{array}{l}\begin{array}{l}\text { Interkulturalitet och } \\
\text { kommunikativ kom- } \\
\text { petens, } 7,5 \mathrm{hp}\end{array} \\
\text { Valbar delkurs: } \\
\text { Kultur och identitet, } \\
\text { 7,5 hp }\end{array}$ & & & $\begin{array}{l}\text { Valbar delkurs: } \\
\text { Kulturkunskap och } \\
\text { interkulturell kom- } \\
\text { munikation, 7,5 hp } \\
\text { (ges inte 2016) }\end{array}$ \\
\hline 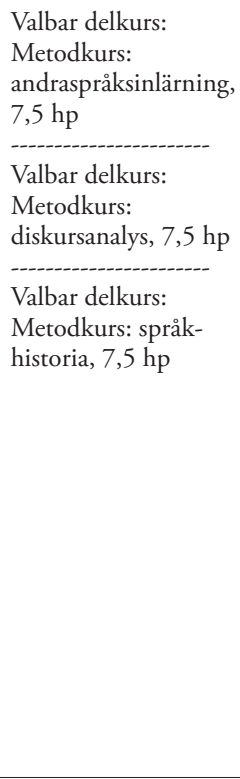 & 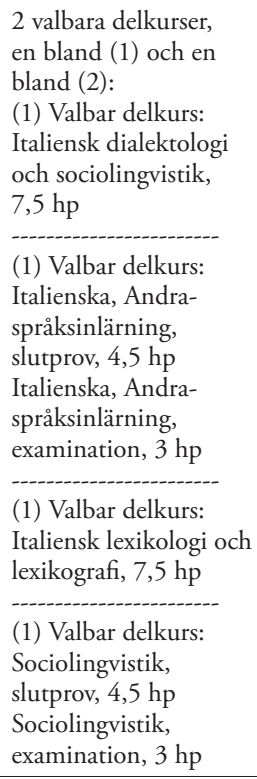 & $\begin{array}{l}\text { Portugisiska, språk- } \\
\text { vetenskap II, 7,5 hp }\end{array}$ & 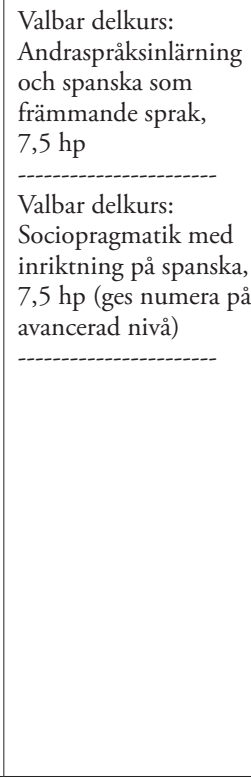 \\
\hline
\end{tabular}

100 Studenterna skriver examensarbete och läser en obligatorisk och en valbar delkurs alternativt den obligatoriska delkursen och tre valbara. Den senare varianten leder inte till kandidatexamen.

101 Studenterna skriver examensarbete och läser två valbara delkurser, en inom språkvetenskap och en inom litteraturvetenskap.

102 Studenterna skriver examensarbete och läser två valbara delkurser. 


\begin{tabular}{|c|c|c|c|}
\hline $\begin{array}{l}\text { Franska } \\
\text {-kandidatkurs }^{100}\end{array}$ & $\begin{array}{l}\text { Italienska } \\
\text {-kandidatkurs }^{101}\end{array}$ & $\begin{array}{l}\text { Portugisiska } \\
\text {-kandidatkurs }\end{array}$ & $\begin{array}{l}\text { Spanska } \\
\text {-kandidatkurs }^{102}\end{array}$ \\
\hline $\begin{array}{l}\text { Valbar delkurs: } \\
\text { Metodkurs: litteratur- } \\
\text { vetenskap, 7,5 hp } \\
\text { Valbar delkurs: } \\
\text { Litterära genrer, 7,5 hp } \\
\text { Valbar delkurs: } \\
\text { Litterära teman, 7,5 hp }\end{array}$ & $\begin{array}{l}\text { (2) Valbar delkurs: } \\
\text { Den fantastiska } \\
\text { litteraturen i Italien, } \\
\text { examination, } 3 \mathrm{hp} \\
\text { Den fantastiska litt. } \\
\text { i Italien, slutprov, } \\
4,5 \text { hp } \\
\text {--a) Valbar delkurs: } \\
\text { Italiensk barnlitteratur, } \\
\text { examination, } 3 \text { hp } \\
\text { Italiensk barnlitteratur, } \\
\text { slutprov, } 4,5 \text { hp } \\
\text {---------------- } \\
\text { (2) Valbar delkurs: } \\
\text { Italienska, nutida } \\
\text { litteratur, examination, } \\
3 \text { hp } \\
\text { Italienska, nutida } \\
\text { litteratur, slutprov, } \\
4,5 \text { hp }\end{array}$ & $\begin{array}{l}\text { Portugisiska, } \\
\text { Litteraturvetenskap } \\
\text { II, 7,5 hp }\end{array}$ & 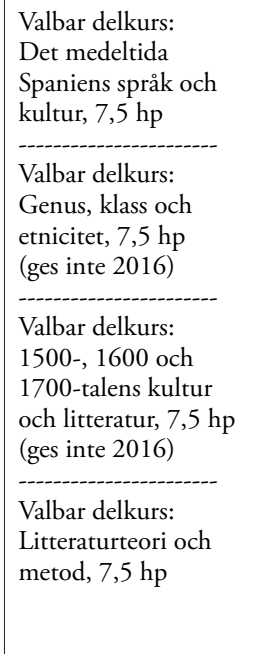 \\
\hline & & & $\begin{array}{l}\text { Valbar delkurs: } \\
\text { Fackspråklig special- } \\
\text { isering med inriktning } \\
\text { på Spanien, } 7,5 \text { hp } \\
\text { (ges inte 2016) } \\
\text {-albar delkurs: } \\
\text { Valbar } \\
\text { Fackspråklig special- } \\
\text { isering med inriktning } \\
\text { på Spanskamerika, } \\
7,5 \text { hp }\end{array}$ \\
\hline
\end{tabular}

\subsubsection{Kandidatnivå: innehåll, förväntade studieresultat och examination}

\section{Obligatoriska delkurser}

\section{Kandidatuppsats}

Avseende examensarbetet tar de fyra kursplanerna upp alla högskoleförordningens examensmål som relaterar till kunskap och förståelse samt till färdighet och förmåga. Enda undantaget är att franskan inte nämner något om att uppgiften ska genomföras inom givna tidsramar. Däremot är det bara franskan som tar upp målen relaterade till värderingsförmåga och för- 
hållningssätt. I de andra ämnena skrivs att studenterna ska beakta gällande forskningsetiska normer, vilket inte täcker förordningens examensmål.

\section{Litteraturvetenskap}

I portugisiskans "Litteraturvetenskap II" ingår läsning av portugisiskspråkiga skönlitterära texter från olika genrer och epoker. Litteraturteorier och metoder med inriktning på portugisiskspråkig litteratur behandlas. Delkursen lägger särskild vikt vid praktiska tillämpningar av litteratursemiotiska begrepp. Studenterna förväntas "visa förmåga att analysera de lästa texterna med hjälp av tillämpade litteraturvetenskapliga verktyg; genom ovannämnda kunskaper kunna identifiera och jämföra de skönlitterära texternas typiska särdrag som hör till de studerade historisklitterära perioderna; relatera ett verk till en samtida idéströmning; sammanställa iakttagelser i ett litterärt verk och presentera dem i en sammanhängande och underbyggd analys på god portugisiska [samt] planera ett forskningsprojekt inom litteraturvetenskap" (Stockholms universitet 2012e).

Delkursen verkar motsvara en kombination av de delkurser om teori och metod som de andra ämnena har på nivå III och de delkurser i litterära strömningar och litteraturhistoria som franska och italienska har på nivå II fast med mindre teoretiskt djup.

\section{Språkvetenskap}

Portugisiskans "Språkvetenskap II" innehåller en fördjupning av centrala begrepp av språkvetenskapliga teorier och metoder med tillämpning på portugisiska. Studenterna förväntas kunna redogöra för centrala teoretiska begrepp och terminologi samt forskningsmetoder och forskningsresultat inom behandlade språkvetenskapliga inriktningar med tillämpning på autentiska språkdata på portugisiska.

\section{Kulturkunskap}

"Interkulturalitet och kommunikativ kompetens" inom kandidatkursen i franska behandlar kommunikation på franska i vid bemärkelse. De förväntade studieresultaten är att kunna "identifiera och muntligt tillämpa retoriska grundbegrepp; interagera och argumentera om såväl förberedda som oförberedda ämnen; redogöra for grundläggande teoribildning inom 
fältet interkulturalitet [samt] resonera kring stereotyper och normer i ett interkulturellt perspektiv" (Stockholms universitet 2015d).

\section{Valbara delkurser}

I det som följer behandlas de valbara delkurser inom franska och spanska som var aktuella hösten 2016. Delkurserna inom franska erbjuds även som valbara kurser på nivå III, som tidigare nämnts. Kurserna i italienska kommenteras inte. Detta beror på bristfällig information i och med att kursplanen inte har någon beskrivning av delkursernas innehåll och har mycket generella förväntade studieresultat som är gemensamma för alla delkurser i språkvetenskap och i litteraturvetenskap. De förväntade studieresultaten för dessa delkurser är att studenterna, med ett rikt och varierat italienskt ordförråd i tal och skrift, ska kunna redogöra för teorier kring det italienska språket eller för litteraturvetenskapliga analyser av italiensk litteratur.

\section{Litteraturvetenskap}

Delkursen "Det medeltida Spaniens språk och kultur" inom kandidatkursen i spanska ger studenterna "kunskaper om samhälle, kultur och litteratur på Iberiska halvön, särskilt inom det kastilianska språkområdet, från 1000-talet till och med 1400-talet". Studenterna övar upp sin "förmåga att läsa medeltida spanska texter och förstå dem i deras historiska, samhälleliga och kulturella sammanhang" (Stockholms universitet 2012g).

I ämnet franska behandlar delkursen "Litterära genrer" franskspråkiga skönlitterära texter som tillhör olika litterära genrer. Studenterna förväntas "redogöra för grundläggande genreteoretiska infallsvinklar; tillämpa narratologiska och genrespecifika termer i litterär analys samt diskutera och tolka litterära texter ur ett genreperspektiv" (Stockholms universitet 2015d).

Vidare inom franskan behandlar delkursen "Litterära teman" skönlitterära texter som speglar olika aspekter av ett specifikt tema i den franskspråkiga litteraturen. Dessa texter studeras och placeras i sina estetiska, idéhistoriska och teoretiska sammanhang. Enligt de förväntade studieresultaten "ska studenterna kunna redogöra för grundläggande inriktningar och begrepp inom litteraturtematisk teoribildning; synliggöra möjliga betydelser av en skönlitterär text utifrån ett tematiskt angreppssätt, integrera viss litterär och utomlitterär kontext i analys av ett tema [samt] analysera tematiska aspekter ur ett jämförande perspektiv" (Stockholms universitet 2015d). 
Delkursen "Litteraturteori och metod", som är obligatorisk på Spanska III, ges som valbar på Spanska IV för studenter som inte läst den inom nivå III då kursen tidigare inte varit obligatorisk. Delkursen har kommenterats under 2.6. Även franskans "Metodkurs: litteraturvetenskap" har kommenterats under 2.6.

\section{Språkvetenskap}

Inom franskan ger "Metodkurs: diskursanalys" "grundläggande insikter i några för diskursanalysen typiska frågeställningar och metodologiskteoretiska infallsvinklar". Studenterna förväntas "kunna redovisa diskursanalysens plats inom och i relation till humanistiska vetenskaper, och i synnerhet till språkvetenskap; redogöra för grundläggande metodologiska och teoretiska infallsvinklar samt definiera grundläggande diskursanalytiska begrepp; diskutera metodens relevans i relation till olika textmaterial [samt] analysera texter på franska med ett urval diskursanalytiska verktyg" (Stockholms universitet 2015d).

Inom franskämnet ger delkursen "Metodkurs: språkhistoria" huvuddragen i franskans utveckling ur vulgärlatinet till modern franska. Även synkrona studier av texter från olika perioder gås igenom. Utöver detta behandlas filologisk metodologi och textutgivning. Studenterna förväntas "karakterisera huvuddragen i franskans utveckling med avseende på fonetik, morfologi, syntax och vokabulär (diakroni); beskriva huvuddragen i språkets utformning under ett urval historiska perioder (synkroni); med hjälp av manualer och ordböcker kunna tillgodogöra sig innehållet i en text på medelfranska [samt] presentera grundläggande metoder för att genomföra en avgränsad forskningsuppgift inom filologi" (Stockholms universitet 2015d).

I ämnet franska ger delkursen "Metodkurs: andraspråksinlärning" huvuddragen i teoribildning, metoder och forskning inom andraspråksinlärning med fokus på generativa, psykologiska och sociala perspektiv. Utöver detta ges en översikt över andraspråksforskningens implikationer för klassrumsundervisningen i språk. Studenterna förväntas kunna "redogöra för centrala teoretiska begrepp och terminologi inom andraspråks- och främmandespråksinlärning; redogöra för centrala resultat inom andraspråksforskningen [samt] med grundläggande metod utföra en analys av autentiska språkdata från inlärare" (Stockholms universitet 2015d). 
Även kandidatkurser i spanska och italienska har delkurser inom det här området. "Andraspråksinlärning och spanska som främmande språk" behandlar teorier och metoder inom andraspråksforskning samt tillämpning på tillägnandet av spanska som främmandespråk. Studenterna förväntas ha förvärvat insikter i teorier och metoder inom andraspråksforskningen både generellt och inom spanska samt inom forskningen på området spanska som andraspråk och främmande språk. Till skillnad från franska finns inga uttalade förväntade studieresultat om att studenterna själva ska kunna analysera data. Med andra ord är kravet på förståelsegrad lägre i spanska än i franska, med tanke på att studenterna enbart förväntas kunna redogöra för den inhämtade kunskapen, inte även kunna tillämpa den (Bloom et al. 1956).

\section{Kulturkunskap}

Delkursen "Kultur och identitet" inom ämnet franska introducerar ett kulturvetenskapligt angreppssätt med problematisering av begrepp som kultur, nation och identitet. Olika sorters kulturfenomen inom den franskspråkiga världen, såväl historiska som samtida, analyseras. Bland de förväntade studieresultaten anges att studenterna ska kunna "utifrån några kulturvetenskapliga förklaringsmodeller redogöra för, och kritiskt granska, bilden av de grundläggande dragen i diskursen kring kultur och identitet i den franskspråkiga världen”. Dessutom ska studenterna "med vetenskapliga redskap utföra en grundläggande analys av samhälleliga och kulturella fenomen i den franskspråkiga världen" (Stockholms universitet 2015d).

Delkursen har flera beröringspunkter med delkursen "Kulturkunskap och interkulturell kommunikation" inom kandidatkurs i spanska, som inte gavs under 2016.

"Fackspråklig specialisering med inriktning på Spanskamerika" inom kandidatkursen i spanska ger fördjupade kunskaper om de spanskamerikanska ländernas sociala, politiska och kulturella liv. Genom läsning av aktuella samhälls- och kulturvetenskapliga texter, vilka analyseras och diskuteras, utvecklar studenterna sin förmåga att kritiskt granska vetenskaplig text, liksom sin muntliga och skriftliga fackspråkliga färdighet.

Sammanfattningsvis kan man säga att två viktiga skillnader finns i sättet på vilket avkodningen av de externa kontexterna (Ball et al. 2012) har genomförts på kandidatnivån. Den första skillnaden har att göra med när- 
varon av högskoleförordningens mål i relation till värderingsförmåga och förhållningssätt. Dessa mål är endast tydligt angivna i franskans kursplan. Den andra skillnaden relaterar till kursplanen i italienskan. Det faktum att högskoleförordningens återkontextualisering inte är så detaljerad kan möjligen tolkas i förhållande till de givna professionella kontexterna (Ball et al. 2012). Man skulle kunna anta att den givna kontexten inom ämnet italienska har varit tillräckligt stabil för att leda till ett mindre behov av att skriva detaljerade kursplaner. I sådana fall spelar den professionella kontexten roll i och med att lärarna har gemensamma erfarenheter som möjliggör användningen av tysta kunskaper.

\subsection{Slutsatser}

Undersökningen visar att den nationella universitetspolicyn genomförs med olika särdrag i de fyra utbildningar i romanska språk som ges vid Romanska och klassiska institutionen vid SU.

Även om kursplanerna uppvisar många gemensamma drag finns det vissa skillnader med avseende på vad som betraktas som viktig kunskap inom huvudområdet. Några olikheter som kan noteras på en given nivå jämnas ut när man ser till hela utbildningarna. Detta är fallet med kunskaperna i semantik som introduceras vid olika tidpunkter i utbildningarna. Andra skillnader består även när man tar hänsyn till helheten. Dessa relaterar till hur stor vikt som fästs vid studiet av pragmatik samt hur djupgående det litteraturteoretiska inslaget och det historiska perspektivet är i de litteraturvetenskapligt inriktade momenten.

Beträffande sättet att kontextualisera högskoleförordningens mål i förhållande till färdigheter och förmågor är skillnaderna avsevärda. Kursplanerna skiljer sig ganska mycket åt i sättet att betrakta hörförståelse, muntlig produktion och interaktion, skriftlig uttrycksfärdighet samt översättning.

När man ser till hela utbildningar märker man att ämnena organiserar färdighetsprogressionen på olika sätt. Spanskan och italienskan fokuserar på skriftlig produktion av akademiska texter på nivå II och behandlar olika textgenrer på nivå III, medan franskan och portugisiskan gör det motsatta, d.v.s. tar upp olika texttyper på nivå II och koncentrerar sig på akademiska genrer på följande nivå. Detta är i vis mån även fallet med det kontrastiva perspektivet. Franskan anlägger ett kontrastivt perspektiv på nivåerna I och 
II. Spanskan gör det på nivå I och III, men inte på nivå II. Portugisiskan arbetar kontrastivt på nivå III och italienskan på nivåerna II och III.

Huruvida dessa sätt att disponera mål och kursinnehåll i olika progressioner främjar att studenterna uppnår högskoleförordningens mål att kunna "visa förmåga att muntligt och skriftligt redogöra för och diskutera information, problem och lösningar ..." går inte att bedöma utan att analysera studenternas produktion, något som inte låter sig göras inom ramen för den här begränsade studien.

Avslutningsvis kan man understryka att den ovannämnda analysen visar att den nationella universitetspolicyn genomförs på olika sätt i de fyra analyserade utbildningarna. Detta kan förklaras med det faktum att Romanska och klassiska institutionen vid SU var ganska ny då undersökningen genomfördes. Den korta gemensamma historien med en helt ny given kontext (Ball et al. 2012) resulterar i en instabilitet där de givna kontexterna som kännetecknade de tidigare institutionerna, institutionen för franska och italienska och klassiska språk samt institutionen för spanska, portugisiska och latinamerikastudier, blir extra viktiga.

Ovanstående beskrivning fångar en bild av studierna i romanska språk i ett tidigt stadium av en institutions existens där de olika tidiga professionella kulturerna (Ball et al. 2012) inte har hunnit hitta gemensamma nämnare. Varje ämne har fortfarande en tydlig egen historia, sina traditioner, sina lokala kulturer och sina lärares olika erfarenheter. Därför vore det intressant att inom en närmare framtid utföra en liknande undersökning för att kunna se på vilket sätt de nya givna och professionella kontexterna präglar utbildningarna i romanska språk och påverkar hur den nationella universitetspolicyn genomförs.

\section{Bibliografi}

Ball, Stephen, 1993: What is policy? Texts, trajectories and toolboxes. The Australian Journal of Education Studies 13:2. 10-17.

Ball, Stephen et al., 2012: How Schools do Policy. Policy Enactments in Secondary Schools. Kent: Routledge.

Bloom, Benjamin, et al., 1956: Taxonomy of Educational Objectives: The Classification of Educational Goals. Handbook 1, Cognitive Domain. New York: David McKay. 
Nationalencyklopedin, 2019: policy. http://www.ne.se.ezp.sub.su.se/ uppslagsverk/ordbok/svensk/policy (hämtad 2019-03-24)

Premat, Christophe, 2018: Pour une généalogie critique de la Francophonie. Stockholm: Stockholm University Press.

SFS 1993:100: Högskoleförordning. Stockholm: Utbildningsdepartementet.

Stockholms universitet, 2012a: Kursplan för kurs på grundnivå Italienska kandidatkurs, 30 högskolepoäng: IT445Z. Stockholm: Stockholms universitet, Romanska och klassiska institutionen.

Stockholms universitet, 2012b: Kursplan för kurs på grundnivå Portugisiska I, 30 högskolepoäng: PO1100. Stockholm: Stockholms universitet, Romanska och klassiska institutionen.

Stockholms universitet, 2012c: Kursplan för kurs på grundnivå Portugisiska II, 30 högskolepoäng: PO2200. Stockholm: Stockholms universitet, Romanska och klassiska institutionen.

Stockholms universitet, 2012d: Kursplan för kurs på grundnivå Portugisiska III, 30 högskolepoäng: PO3300. Stockholm: Stockholms universitet, Romanska och klassiska institutionen.

Stockholms universitet, 2012e: Kursplan för kurs på grundnivå Portugisiska kandidatkurs, 30 högskolepoäng: PO4400. Stockholm: Stockholms universitet, Romanska och klassiska institutionen.

Stockholms universitet, 2012f: Kursplan för kurs på grundnivå Spanska III, 30 högskolepoäng: ES3300. Stockholm: Stockholms universitet, Romanska och klassiska institutionen.

Stockholms universitet, 2012g: Kursplan för kurs på grundnivå Spanskakandidatkurs, 30 högskolepoäng: ES4400. Stockholm: Stockholms universitet, Romanska och klassiska institutionen.

Stockholms universitet, 2014: Kursplan för kurs på grundnivå Italienska III, 30 högskolepoäng: IT347Z. Stockholm: Stockholms universitet, Romanska och klassiska institutionen.

Stockholms universitet, 2015a: Kursplan för kurs på grundnivå Franska I, 30 högskolepoäng: FR130A. Stockholm: Stockholms universitet, Romanska och klassiska institutionen.

Stockholms universitet, 2015b: Kursplan för kurs på grundnivå Franska II, 30 högskolepoäng: FR230A. Stockholm: Stockholms universitet, Romanska och klassiska institutionen.

Stockholms universitet, 2015c: Kursplan för kurs på grundnivå Franska III, 30 högskolepoäng: FR330A. Stockholm: Stockholms universitet, Romanska och klassiska institutionen. 
Stockholms universitet, 2015d: Kursplan för kurs på grundnivå Franska kandidatkurs, 30 högskolepoäng: FRK30A. Stockholm: Stockholms universitet, Romanska och klassiska institutionen.

Stockholms universitet, 2015e: Kursplan för kurs på grundnivå Italienska I, 30 högskolepoäng: IT130A. Stockholm: Stockholms universitet, Romanska och klassiska institutionen.

Stockholms universitet, 2015f: Kursplan för kurs på grundnivå Spanska I, 30 högskolepoäng: ES100A. Stockholm: Stockholms universitet, Romanska och klassiska institutionen.

Stockholms universitet, 2015g: Kursplan för kurs på grundnivå Spanska II, 30 högskolepoäng: ES230A. Stockholm: Stockholms universitet, Romanska och klassiska institutionen.

Stockholms universitet, 2016: Kursplan för kurs på grundnivå Italienska II, 30 högskolepoäng: IT230A. Stockholm: Stockholms universitet, Romanska och klassiska institutionen.

Stockholms universitet, 2017: Franska, italienska, spanska, portugisiska, romanska och klassiska språk. https:/www.su.se/utbildning/examen/examensregler/ examensbeskrivningar/humaniora-och-språk/franska-italienska-spanskaportugisiska-romanska-och-klassiska-språk-1.262202. [2017-02-11]. 